\title{
STUDY OF PREVALENCE OF DIABETIC RETINOPATHY AND CORRELATION WITH RISK FACTORS
}

\author{
D. V. C. Nagasree1, Ramakrishna Rachakonda²
}

${ }_{1}^{1}$ Associate Professor, Department of Ophthalmology, NRI Medical College, Chinakakani, Guntur, Andhra Pradesh, India.

2Professor and HOD, Department of Pulmonary Medicine, NRI Medical College, Chinakakani, Guntur, Andhra Pradesh, India.

\section{BACKGROUND}

ABSTRACT

Diabetes mellitus is increasing in our society, so are the complications of diabetes mellitus. Diabetic retinopathy is a common cause of preventable blindness. We have taken a total of 1053 diabetic patients in our tertiary centre and studied 302 patients of Diabetic retinopathy diagnosed in the Department of Ophthalmology as a cross-sectional institution-based descriptive study from April 2016 to October 2017 in our tertiary care centre.

\section{MATERIALS AND METHODS}

We studied 302 patients of diabetic retinopathy and graded them into five grades of retinopathy. The severity of retinopathy is correlated with age, sex, duration of diabetes mellitus, systolic and diastolic blood pressure, BMI, albuminuria, smoking status and alcohol consumption.

\begin{abstract}
RESULTS
Among the 302 diabetic retinopathy patients, there is a male predominance among diabetics. Females outnumbered males in the diabetic retinopathy group. Female preponderance in DR is not significant. There is an age-related increase in diabetic retinopathy, but the values are not statistically significant. $60 \%$ of our patients of DR are agricultural labourers in our study. Average age of diabetic retinopathy patients in our study is around 54. Duration of diabetes increased the prevalence of DR, but the values are not significant in our study. Systolic blood pressure, albuminuria and smoking history correlated with severity of DR ( $p$-value $<0.05$ ). BMI, alcoholism and diastolic blood pressure did not correlate with severity of diabetic retinopathy.
\end{abstract}

\section{CONCLUSION}

There is a statistically significant correlation between severity of Diabetic retinopathy and systolic blood pressure, albuminuria and smoking. Other factors like female preponderance, higher BMI, diastolic blood pressure and alcohol intake were high among patients of diabetic retinopathy, but the values did not show statistically significant correlation with the severity of diabetic retinopathy.

\section{KEY WORDS}

Diabetic Retinopathy, Albuminuria, Systolic Blood Pressure, Diastolic Blood Pressure, Albuminuria, Smoking, Alcoholism.

HOW TO CITE THIS ARTICLE: Nagasree DVC, Rachakonda R. Study of prevalence of diabetic retinopathy and correlation with risk factors. J. Evolution Med. Dent. Sci. 2018;7(31):3452-3456, DOI: 10.14260/jemds/2018/778

\section{BACKGROUND}

Diabetes mellitus is a chronic disease arising from absolute or relative deficiency of insulin. Globally, an estimated 422 million adults were living with diabetes in 2014 compared to 108 million in 1980 . Globally, $8.5 \%$ adult population are suffering from Diabetes mellitus. ${ }^{1}$ Both Type I and Type II forms of diabetes can lead to multisystem complications of microvascular disease including retinopathy, nephropathy and neuropathy, ischaemic heart disease, stroke and peripheral vascular disease. The premature morbidity, mortality, reduced life expectancy and financial and other costs of diabetes make it an important public health condition. ${ }^{2}$

Diabetic retinopathy is a chronic progressive, potentially sight-threatening disease of the retinal microvasculature associated with the prolonged hyperglycaemia and other conditions linked to diabetes mellitus such as hypertension.

'Financial or Other Competing Interest': None.

Submission 03-04-2018, Peer Review 14-07-2018,

Acceptance 20-07-2018, Published 28-07-2018.

Corresponding Author:

D. V. C. Nagasree,

Sanjeevani Hospital, A1, Ramkuteer Majestic,

3/13, Brodipet, Guntur, Andhra Pradesh, India.

E-mail: ramakrishna45@yahoo.co.in

DOI: $10.14260 /$ jemds $/ 2018 / 778$

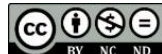

Diabetic retinopathy is a potentially blinding disease in which the threat to sight comes through two main routes: growth of new vessels leading to intraocular haemorrhage and possible retinal detachment with profound global sight loss and localised damage to the macula/ fovea of the eye with loss of central visual acuity. ${ }^{3}$

Environmental and lifestyle changes resulting from industrialisation and migration to urban environment from rural settings may be responsible to a large extent for this epidemic of Type 2 diabetes in Indians. Obesity, especially central obesity and increased visceral fat due to physical inactivity and consumption of a high-calorie/ high-fat and high sugar diets are major contributing factors. There is also strong evidence that Indians have a greater degree of insulin resistance and a stronger genetic predisposition to diabetes. One-third of the world's burden of Diabetes is borne by India and China. ${ }^{4}$ The overall prevalence of pre-diabetes in 15 states in India was $10.3 \% .^{5}$ The prevalence of diabetes among adults has reached approximately $20 \%$ in urban populations and approximately $10 \%$ in rural populations. ${ }^{6}$

Relevance of Diabetic retinopathy in India: India has more than 62 million Diabetic individuals and many more undiagnosed and as a result Diabetic retinopathy is emerging as an important cause of visual disability, reported by World Health Organisation.7,8,9,10 It was estimated that about 5.5 million adult patients with Diabetes have Diabetic 
retinopathy. About 50,000 new cases of blindness occur per year, out of which $50 \%$ are caused by Diabetes, that too mostly by Diabetic retinopathy. ${ }^{11}$

Diabetes mellitus is known to produce the microvascular complications ${ }^{12}$ and hyperlipidaemia causes endothelial dysfunction due to reduced bioavailability of Nitric Oxide and breakdown of Blood-Retinal Barrier leading to exudation of serum lipid and lipoproteins, which result in Diabetic retinopathy changes and Diabetic macular oedema formation. ${ }^{13,14}$ The established risk factors for development and progression of Diabetic retinopathy include: Type, Duration, Age, Gender, BMI, Glycaemic control, Hypertension, Nephropathy, Smoking, Pregnancy and Serum lipid levels. ${ }^{15,16}$

\section{Aims and Objectives}

1. To study the prevalence of Diabetic retinopathy among diabetic patients.

2. To study the demographic data and co-factors in diabetic retinopathy patients.

3. To study the influence of Duration of Diabetes, BMI, Systolic and Diastolic blood pressures, Smoking, Alcoholism and Albuminuria among Diabetic Retinopathy patients.

4. To correlate the various parameters with the severity of Diabetic retinopathy for the purpose of preventing visual loss.

\section{Study Design}

It is a cross-sectional institution-based descriptive study from April 2016 to October 2017 in a tertiary care centre.

\section{MATERIALS AND METHODS}

\section{Inclusion Criteria}

1. All the patients diagnosed as Diabetic Retinopathy above 20 years of age.

2. Patients of both sexes are taken into the study.

\section{Exclusion Criteria}

Non-cooperative patients and patients with Diabetic retinopathy who are seriously ill with other complications.

\section{Methodology}

Among a total of 335 diabetic retinopathy patients, 33 patients were excluded because of non-cooperation or seriousness of associated illness. 302 patients of Diabetic retinopathy were included in the study.

All the 302 patients with diabetic retinopathy were subjected to dilated fundoscopy with $90+\mathrm{D}$ lens direct ophthalmoscopy and were graded as follows-

- Microaneurysm(s) only- Grade I.

- $\quad$ Mild NPDR- Grade II.

- Moderate NPDR- Grade III.

- Severe NPDR- Grade IV.

- $\quad$ Proliferative DR-Grade V.

Prevalence of Diabetic retinopathy, age, sex, occupation, duration of diabetes, BMI, systolic and diastolic blood pressure, smoking history and alcoholic history of these patients were studies. Routine blood and urine examination was done. Presence of albuminuria was noted. All the parameters were correlated with the severity of Diabetic retinopathy.

\section{Statistical Analysis}

Descriptive statistics were used to present the findings. Chisquare test of association was used to study the association between severity of retinopathy and different variables under study. Pearson's Chi-square test is used as statistical hypothesis test and Chi-square calculator for a contingency table that has up to five rows and columns is used for calculation. IBM Corp. Released 2016. IBM SPSS Statistics for Windows, Version 24.0. Armonk, NY: IBM Corp. is used as the statistical tool.

\begin{tabular}{|c|c|c|c|c|}
\hline $\begin{array}{c}\text { Sl. } \\
\text { No. }\end{array}$ & $\begin{array}{c}\text { Total No. } \\
\text { Studied }\end{array}$ & Cofactor & $\begin{array}{c}\text { No. of } \\
\text { Patients }\end{array}$ & $\%$ \\
\hline 1. & 302 & Female sex & 158 & $52.32 \%$ \\
\hline 2. & 302 & Age above 40 years & 266 & $88 \%$ \\
\hline 3. & 302 & $\begin{array}{c}\text { Duration of DM }>10 \\
\text { years }\end{array}$ & 204 & $67.54 \%$ \\
\hline 4. & 302 & SBP > 130 mmHg & 243 & 80.46 \\
\hline 5. & 302 & DBP> 90 mmHg & 247 & $81.79 \%$ \\
\hline 6. & 302 & $\begin{array}{c}\text { BMI > 25 kg/meter } \\
\text { square }\end{array}$ & 205 & $67.88 \%$ \\
\hline 7. & 302 & Albuminuria & 264 & $87.41 \%$ \\
\hline 8. & 302 & $\begin{array}{c}\text { Current or Ex- } \\
\text { Smokers }\end{array}$ & 210 & $69.5 \%$ \\
\hline 9. & 302 & $\begin{array}{c}\text { Alcohol } \\
\text { Consumption }\end{array}$ & 29 & $9.60 \%$ \\
\hline \multicolumn{5}{|c|}{ Table 1 } \\
\hline
\end{tabular}

\begin{tabular}{|c|c|c|}
\hline $\begin{array}{c}\text { Total No. of } \\
\text { Diabetic Patients }\end{array}$ & $\begin{array}{c}\text { No. of Patients with } \\
\text { Retinopathy }\end{array}$ & Percentage \\
\hline 1053 & 335 & $31.81 \%$ \\
\hline \multicolumn{3}{|c|}{ Table 2 } \\
\hline
\end{tabular}

Male Diabetics 557 and Female Diabetics 496. Ratio is $52.89 \%: 47.11 \%$. Average age of diabetic retinopathy patients is 54.44

\begin{tabular}{|c|c|c|c|c|c|c|}
\hline $\begin{array}{c}\text { Grade of } \\
\text { Retinopathy }\end{array}$ & $\begin{array}{c}\mathbf{2 0 - 3 0} \\
\text { Years }\end{array}$ & $\begin{array}{c}\mathbf{3 0 - 4 0} \\
\text { Years }\end{array}$ & $\begin{array}{c}\mathbf{4 0 - 5 0} \\
\text { Years }\end{array}$ & $\begin{array}{c}\mathbf{5 0 - 6 0} \\
\text { Years }\end{array}$ & $\begin{array}{c}>60 \\
\text { Years }\end{array}$ & Total \\
\hline Grade I & 02 & 03 & 22 & 39 & 18 & 84 \\
\hline Grade II & 04 & 06 & 26 & 49 & 19 & 104 \\
\hline Grade III & 01 & 12 & 21 & 42 & 06 & 82 \\
\hline Grade IV & 02 & 03 & 02 & 04 & 05 & 16 \\
\hline Grade V & 01 & 01 & 02 & 09 & 03 & 16 \\
\hline Total & $\mathbf{1 0}$ & $\mathbf{2 5}$ & $\mathbf{7 3}$ & $\mathbf{1 4 3}$ & $\mathbf{5 0}$ & $\mathbf{3 0 2}$ \\
\hline Table 3. Age Distribution of Diabetic Retinopathy Patients \\
\hline \multicolumn{7}{|c|}{}
\end{tabular}

The Chi-square statistic for age is 26.9195 . The $\mathrm{p}$-value is 0.042386 . The result is significant at $\mathrm{p}-<0.05$.

\begin{tabular}{|c|c|c|c|c|}
\hline $\begin{array}{c}\text { Grade of } \\
\text { Retinopathy }\end{array}$ & Males & Females & Total & Percentage \\
\hline Grade I & 36 & 48 & 84 & $27.81 \%$ \\
\hline Grade II & 49 & 55 & 104 & $34.44 \%$ \\
\hline Grade III & 43 & 39 & 82 & $27.15 \%$ \\
\hline Grade IV & 08 & 08 & 16 & $5.29 \%$ \\
\hline Grade V & 08 & 08 & 16 & $5.29 \%$ \\
\hline Total & $\mathbf{1 4 4}$ & $\mathbf{1 5 8}$ & $\mathbf{3 0 2}$ & $\mathbf{1 0 0}$ \\
\hline Percentage & $\mathbf{4 7 . 6 8 \%}$ & $\mathbf{5 2 . 3 2 \%}$ & $\mathbf{3 0 2}$ & $\mathbf{1 0 0}$ \\
\hline Table 4. Sex Distribution of patients of Diabetic \\
Retinopathy \\
\hline
\end{tabular}


The Chi-square statistic for female preponderance is 1.61 . The p-value is 0.806991 . The result is not significant at $\mathrm{p}<0.05$.

\begin{tabular}{|c|c|c|}
\hline Profession & No. of Patients & Percentage \\
\hline Agricultural Workers & 181 & $59.93 \%$ \\
\hline Skilled Labourers & 076 & $25.16 \%$ \\
\hline Others & 045 & $14.90 \%$ \\
\hline Table 5. Professional Occupational Analysis of Diabetic \\
Retinopathy Patients \\
\hline
\end{tabular}

\begin{tabular}{|c|c|c|c|c|c|}
\hline $\begin{array}{c}\text { Grade of } \\
\text { DR }\end{array}$ & $\begin{array}{c}\mathbf{0 - 5} \\
\text { Years }\end{array}$ & $\begin{array}{c}\mathbf{5 - 1 0} \\
\text { Years }\end{array}$ & $\begin{array}{c}\mathbf{1 0 - 1 5} \\
\text { Years }\end{array}$ & $\begin{array}{c}>15 \\
\text { Years }\end{array}$ & Total \\
\hline Grade I & 11 & 13 & 28 & 32 & 84 \\
\hline Grade II & 09 & 21 & 39 & 34 & 104 \\
\hline Grade III & 16 & 16 & 28 & 22 & 82 \\
\hline Grade IV & 02 & 02 & 09 & 03 & 16 \\
\hline Grade V & 03 & 04 & 07 & 02 & 16 \\
\hline
\end{tabular}

Table 6. Duration of DM and Grade of Retinopathy

The Chi-square statistic is 12.3856 and the p-value is .415232 and the value are not significant for $\mathrm{p}<0.05$.

\begin{tabular}{|c|c|c|c|c|c|}
\hline $\begin{array}{c}\text { Grade of } \\
\text { DR }\end{array}$ & $\begin{array}{c}\text { SBP 100- } \\
\mathbf{1 3 0} \\
\mathbf{m m H g}\end{array}$ & $\begin{array}{c}\text { SBP 130- } \\
\mathbf{1 6 0} \\
\mathbf{m m H g}\end{array}$ & $\begin{array}{c}\text { SBP 160 } \\
\text { to 190 } \\
\mathbf{m m H g}\end{array}$ & $\begin{array}{c}\text { SBP > } \\
\mathbf{1 9 0} \\
\mathbf{m m H g}\end{array}$ & Total \\
\hline Grade I & 22 & 16 & 36 & 10 & 84 \\
\hline Grade II & 17 & 29 & 42 & 15 & 104 \\
\hline Grade III & 14 & 32 & 25 & 10 & 82 \\
\hline Grade IV & 02 & 05 & 04 & 05 & 16 \\
\hline Grade V & 02 & 05 & 03 & 06 & 16 \\
\hline Table 7. Systolic Blood Pressure and Diabetic Retinopathy \\
\hline
\end{tabular}

The Chi-square statistic for SBP is 22.5108 and p-value is 0.032179 . The result is significant at $\mathrm{p}<0.05$.

\begin{tabular}{|c|c|c|c|c|c|}
\hline $\begin{array}{c}\text { Grade of } \\
\text { DR }\end{array}$ & $\begin{array}{c}\text { DBP }<\mathbf{9 0} \\
\mathbf{m m H g}\end{array}$ & $\begin{array}{c}\mathbf{9 0} \text { to } \\
\mathbf{1 0 0} \\
\mathbf{m m H g}\end{array}$ & $\begin{array}{c}\mathbf{1 0 0} \text { to } \\
\mathbf{1 1 0} \\
\mathbf{m m H g}\end{array}$ & $\begin{array}{c}\mathbf{> 1 1 0} \\
\mathbf{m m H g}\end{array}$ & Total \\
\hline Grade I & 11 & 27 & 32 & 14 & 84 \\
\hline Grade II & 21 & 21 & 39 & 22 & 104 \\
\hline Grade III & 19 & 21 & 29 & 13 & 82 \\
\hline Grade IV & 02 & 04 & 04 & 06 & 16 \\
\hline Grade V & 02 & 04 & 04 & 06 & 16 \\
\hline
\end{tabular}

Table 8. Diastolic Blood Pressure and Diabetic Retinopathy

The Chi-square statistic for DBP is 13.0136. The p-value is 0.368055 . The result is not significant at $\mathrm{p}<0.05$.

\begin{tabular}{|c|c|c|c|c|c|}
\hline $\begin{array}{c}\text { Grade of } \\
\text { Retinopathy }\end{array}$ & BMI < 20 & $\mathbf{2 0 - 2 5}$ & $\mathbf{2 5 - 3 0}$ & $\mathbf{> 3 0}$ & Total \\
\hline Grade I & 06 & 15 & 31 & 32 & 84 \\
\hline Grade II & 18 & 13 & 34 & 38 & 104 \\
\hline Grade III & 22 & 11 & 27 & 22 & 82 \\
\hline Grade IV & 03 & 02 & 04 & 07 & 16 \\
\hline Grade V & 04 & 02 & 05 & 05 & 16 \\
\hline \multicolumn{7}{|r|}{ Table 9. Diabetic Retinopathy and BMI } \\
\hline
\end{tabular}

The Chi-square statistic for BMI is 13.759. The p-value is 0.316362 . The value is not statistically significant at $\mathrm{p}<0.05$.

\begin{tabular}{|c|c|c|c|}
\hline Retinopathy & $\begin{array}{c}\text { Patients with } \\
\text { Albuminuria= 264 }\end{array}$ & $\begin{array}{c}\text { Patients with No } \\
\text { Albuminuria= 38 }\end{array}$ & $\begin{array}{c}\text { Total } \\
\mathbf{3 0 2}\end{array}$ \\
\hline Grade I & 76 & 08 & 84 \\
\hline Grade II & 93 & 11 & 104 \\
\hline Grade III & 74 & 08 & 82 \\
\hline Grade IV & 09 & 07 & 16 \\
\hline Grade V & 12 & 04 & 16 \\
\hline
\end{tabular}

Table 10. Albuminuria and Diabetic Retinopathy

The Chi-square statistic is 18.0635. The p-value is 0.001199 . The result is statistically significant at $p<0.05$.

\begin{tabular}{|c|c|c|c|c|}
\hline Retinopathy & $\begin{array}{c}\text { Non- } \\
\text { Smokers } \\
\mathbf{9 2}\end{array}$ & $\begin{array}{c}\text { Ex- } \\
\text { Smokers } \\
\mathbf{= 1 5 4}\end{array}$ & $\begin{array}{c}\text { Current } \\
\text { Smokers } \\
\mathbf{5} \mathbf{5 6}\end{array}$ & $\begin{array}{c}\text { Total } \\
\mathbf{3 0 2}\end{array}$ \\
\hline Grade I & 32 & 36 & 16 & 84 \\
\hline Grade II & 18 & 63 & 23 & 104 \\
\hline Grade III & 31 & 42 & 09 & 82 \\
\hline Grade IV & 05 & 06 & 05 & 16 \\
\hline Grade V & 06 & 07 & 03 & 16 \\
\hline \multicolumn{6}{|r}{ Table 11. Smoking and Diabetic Retinopathy } \\
\hline
\end{tabular}

The Chi-square statistic is 17.5823. The $p$-value is 0.024586 . The result is statistically significant at $p<0.05$.

\begin{tabular}{|c|c|c|c|}
\hline Retinopathy & $\begin{array}{c}\text { Alcohol } \\
\text { Consumption Not } \\
\text { Present = 273 }\end{array}$ & $\begin{array}{c}\text { Alcohol } \\
\text { Consumption } \\
\text { Present = 29 }\end{array}$ & $\begin{array}{c}\text { Total } \\
\mathbf{= 3 0 2}\end{array}$ \\
\hline Grade I & 77 & 07 & 84 \\
\hline Grade II & 92 & 12 & 104 \\
\hline Grade III & 77 & 05 & 82 \\
\hline Grade IV & 13 & 03 & 16 \\
\hline Grade V & 14 & 02 & 16 \\
\hline \multicolumn{2}{|r|}{ Table 12. Alcohol Consumption and Diabetic Retinopathy } \\
\hline
\end{tabular}

The Chi-square statistic is 3.4624 . The p-value is .483612 . The result is not significant at $\mathrm{p}<0.05$.

\begin{tabular}{|c|c|c|c|c|}
\hline $\begin{array}{c}\text { Sl. } \\
\text { No. }\end{array}$ & Variable & Chi-square & P-value & $\begin{array}{c}\text { Significance } \\
\mathbf{p}<.05\end{array}$ \\
\hline 1. & Age Distribution & 26.9195 & 0.042386 & Significant \\
\hline 2. & Duration of DM & 12.3856 & 0.415232 & $\begin{array}{c}\text { Not } \\
\text { Significant }\end{array}$ \\
\hline 3. & $\begin{array}{c}\text { Systolic Blood } \\
\text { Pressure }\end{array}$ & 22.5108 & 0.032179 & Significant \\
\hline 4. & Diastolic BP & 13.0136 & 0.368055 & $\begin{array}{c}\text { Not } \\
\text { Significant }\end{array}$ \\
\hline 5. & BMI & 13.759 & 0.316362 & $\begin{array}{c}\text { Not } \\
\text { Significant }\end{array}$ \\
\hline 6. & Albuminuria & 18.0635 & 0.001199 & Significant \\
\hline 7. & Smoking & 17.5823 & 0.024586 & Significant \\
\hline 8. & $\begin{array}{c}\text { Alcohol } \\
\text { consumption }\end{array}$ & 3.4624 & 0.483612 & $\begin{array}{c}\text { Not } \\
\text { Significant }\end{array}$ \\
\hline \multicolumn{3}{|c|}{ Table 13. Summarised Statistical Analysis } \\
\hline
\end{tabular}

\section{RESULTS}

$31.81 \%$ of the diabetes mellitus patients were found to have Diabetic retinopathy. Average age of DR patients is 54 years.

Predominant number of patients of DR are females. Female: Male Ratio is 52.32:47.68, though there is male preponderance among diabetic patients 52.89: 47.11. But the value is not statistically significant.

Diabetic retinopathy occurred in predominantly above 40 years' age group. 
There is a statistically significant increase in grades of retinopathy with increased age.

$60 \%$ of the patients in our study are agriculture workers and $25 \%$ skilled labourers.

In our study, prevalence of DR increased with increase in duration of Diabetes mellitus. But the value is not statistically significant.

There is a statistically significant increase in prevalence of DR with increase in systolic blood pressure.

There is an increase in prevalence of DR with increase in Diastolic blood pressure, but the value is not statistically significant.

195 cases out of a total of 302 cases belong to group of 25 and above BMI. But the value in our study is not statistically significant.

Albuminuria in our study statistically correlated with the severity of Diabetic retinopathy.

Smoking correlated with severity of Diabetic retinopathy.

History of alcoholism did not correlate with severity of Diabetic Retinopathy.

\section{DISCUSSION}

Though the number of diabetics were more among the men, retinopathy is predominant among women in our study. A Pakistani study also showed female preponderance. The study showed a prevalence of $23.9 \%$ of DR, which is similar to our study. ${ }^{17}$ Female predominance in our study is not statistically significant. A large Japanese study also showed female predominance. $29.6 \%$ of their diabetic patients had retinopathy. ${ }^{18}$ Another Indian study showed that duration of Diabetes and Diastolic Blood pressure showed a positive association with diabetic retinopathy with male predominance. ${ }^{19}$ The prevalence of DR in the Chennai Urban Rural Epidemiology (CURES) Eye Study in south India was 17.6 percent. CURES Eye study showed that the major systemic risk factors for onset and progression of DR are duration of diabetes, degree of glycaemic control and hyperlipidaemia. Hypertension did not play a major role in this cross-sectional analysis. ${ }^{9}$ In our study, smoking but not alcoholism correlated with severity of DR. Hammes et al study revealed significant correlation of glycaemic control, HDL-cholesterol and diastolic blood pressure on the occurrence of retinopathy. ${ }^{20}$ An Italian study showed Systolic BP was significantly related to Diabetic retinopathy, but Diastolic BP was not significantly related, and our study showed similar results. ${ }^{21}$

\section{CONCLUSION}

Diabetic retinopathy is a significant complication of diabetes mellitus, which is a cause of preventable blindness or Sight Threatening Retinopathy (STDR). Prevalence of diabetic retinopathy among diabetic patients in our study is $31.81 \%$. Average age of Diabetic retinopathy patients is around 54 years. Several studies correlated development of DR and severity with duration of DM, systolic and diastolic hypertension, BMI, albuminuria, smoking, alcoholism and decreased vitamin D levels. Our study correlated with statistically significant figures with regards to Systolic blood pressure, albuminuria and smoking. Other factors like female preponderance, higher BMI, diastolic blood pressure and alcohol intake were high among patients of diabetic retinopathy, but the values did not show statistically significant correlation with the severity of diabetic retinopathy.

\section{Abbreviations}

DR: Diabetic Retinopathy; NPDR: Non-Proliferative Diabetic Retinopathy; BMI: Body Mass Index; NPDR: Non-Proliferative Diabetic Retinopathy; STDR: Sight Threatening Diabetic Retinopathy.

\section{REFERENCES}

[1] Margaret Chan. Director-General, WHO, Global Report on Diabetes, World Health Organization 2016. ISBN 9789241565257 (NLM classification: WK 810)

[2] Forouhi NG, Wareham NJ. Epidemiology of diabetes. Medicine (Abington) 2014;42(12):698-702.

[3] Ghanchi F. Bailey MC, Chakravarthy PU, et al. Diabetic Retinopathy Guidelines December 2012, The Royal College of Ophthalmologists 2012.

[4] Mohan V. Why are Indians more prone to diabetes? J Assoc Physicians India 2004;52:468-74.

[5] Anjana RM, Deepa M, Pradeepa R, et al. Prevalence of diabetes and pre-diabetes in 15 states of India: results from the ICMR-INDIAB population-based crosssectional study. Lancet Diabetes Endocrinol 2017;5(8):585-96.

[6] Ramachandran A, Snehalatha C. Current scenario of diabetes in India. Journal of Diabetes 2009;1(1):18-28.

[7] Joshi SR, Parikh RM. India-diabetes control of the world: now heading towards hypertension. J Assoc Physicians India 2007;55:323-4.

[8] Kumar A, Goel MK, Jain RB, et al. India towards diabetes control: key issues. Australas Med J 2013;6(10):524-31.

[9] Rema M, Pradeepa R. Diabetic retinopathy-an Indian perspective. Indian J Med Res 2007;125(3):297-310.

[10] Wild S, Roglic G, Green A, et al. Global prevalence of diabetes, estimates for the year 2000 and projections for 2030. Diabetes Care 2004;27(5):1047-53.

[11] R\&B legend Gladys Knight Sings praises of early detection and management of diabetes. Schaumberg (IL). Prevent Blindness America, 2003.

[12] Ciulla TA, Amador AG, Zinman B. Diabetic retinopathy and diabetic macular edema: patho-physiology, screening and novel therapies. Diabetes Care 2003;26(9):2653-64.

[13] Agroiya P, Philip R, Saran S, et al. Association of serum lipids with diabetic retinopathy in type 2 diabetes. Indian J Endocr Metab 2013;17(Suppl 1):S335-7.

[14] Cetin EN, Bulgu Y, Ozdemir S, et al. Association of serum lipid levels with diabetic retinopathy. Intl J Ophthalmol 2013;6(3):346-9.

[15] Kanski JJ, Bowling B. Retinal vascular disease. In: Kanski JJ, edr. Clinical ophthalmology - a systematic approach. $7^{\text {th }}$ edn. London: Elsevier Saunders 2011: p. 533-91.

[16] Javadi MA, Katibeh M, Rafati N, et al. Prevalence of diabetic retinopathy in Tehran province: a populationbased study. BMC Ophthalmol 2009;9:12.

[17] Hussain S, Qamar MR, Iqbal MA, et al. Risk factors of retinopathy in type 2 diabetes mellitus at a tertiary care hospital, Bahawalpur Pakistan. Pak J Med Sci 2013;29(2):536-9. 
[18] Kawasaki S, Satoh S, Hasegawa 0, et al. Female preponderance in the discordant association between retinopathy and nephropathy in patients with type 2 diabetes mellitus. International Journal of Clinical Medicine 2011;2:13-7.

[19] Shivayogi R, Kusagur. Prevalence of diabetic retinopathy in type II diabetes in relation to risk factors, a hospital based study. JEMDS 2014;3(20):5513-22.
[20] Hammes HP, Kerner W, Hofer S, et al. Diabetic retinopathy in type 1 diabetes - a contemporary analysis of 8,784 patients. Diabetologia 2011;54(8):1977-84.

[21] Penno G, Solini A, Bonora E, et al. HbA1c variability as an independent correlate of nephropathy, but not retinopathy, in patients with Type 2 Diabetes: the Renal Insufficiency and Cardiovascular Events (RIACE) Italian multicentre study. Diabetes Care 2013;36(8):2301-10. 